Article

\title{
An Investigation of the Influence of the Worldwide Governance and Competitiveness on Accounting Fraud Cases: A Cross-Country Perspective
}

\author{
Rabeea Sadaf ${ }^{1}$, Judit Oláh ${ }^{2}$ (D) József Popp ${ }^{3}$ and Domicián Máté ${ }^{4, *(D)}$ \\ 1 Faculty of Economics and Business, Institute of Accounting and Finance, Controlling Department, \\ University of Debrecen, Ihrig Károly PhD School, 4028 Debrecen, Hungary; rabeea.sadaf@econ.unideb.hu \\ 2 Faculty of Economics and Business, Institute of Applied Informatics and Logistics, University of Debrecen, \\ 4032 Debrecen, Hungary; olah.judit@econ.unideb.hu \\ 3 Faculty of Economics and Business, Institute of Sectoral Economics and Methodology, \\ University of Debrecen, 4032 Debrecen, Hungary; popp.jozsef@econ.unideb.hu \\ 4 Faculty of Economics and Business, Institute of Accounting and Finance, Controlling Department, \\ University of Debrecen, 4028 Debrecen, Hungary \\ * Correspondence: mate.domician@econ.unideb.hu; Tel.: +36-20-991-5258
}

Received: 30 January 2018; Accepted: 22 February 2018; Published: 26 February 2018

\begin{abstract}
This article examines how worldwide governance, global competiveness, and other institutional determinants have influenced the number of accounting fraud cases in several countries. The researchers have focused more closely on the importance of 'good governance' as one of the indicators of development objectives in itself. The institutional perspective is employed to explain the complexity of frauds in different societies which can be compatible for the purposes of international judgments in order to increase the effectiveness of previous forensic accounting theories. In this paper, a linear regression model is tested where governance, competitiveness, and other institutional variables are associated with a measure of accounting fraud cases. From our results, we can merely claim that an increased level of controlled corruption and political stability might reduce the number of fraud cases in various countries, while more effective and independent governance services with a higher freedom of expression seemed to increase them. The existence of accounting crimes also appeared to be a suitable proxy of better competitiveness. Anglo-Saxon countries have more stated fraud cases than other countries, attributed, perhaps, to the finest commercial courts with the most professional and least corrupt judges in the world, with centuries of precedent cases and experience in dealing with fraud. Moreover, we believe that a better understanding of fraud detection is a potentially important element in forensic accounting analytics in the success of governance policies to enhance development and reduce the risk of bankruptcies related to the reported fraud cases of enterprises.
\end{abstract}

Keywords: worldwide governance; global competitiveness; accounting fraud cases; institutions; cross-country analysis

\section{Introduction}

The notion of forensic accounting is often described as litigation involving fraud, bankruptcy, valuation, etc., and a variety of additional services [1]. Forensic frauds, in the broadest sense, are defined as knowing misrepresentations of the truth or concealment of a material fact to induce another to act to their detriment [2]. Consequently, fraud includes any intentional or deliberate action to deprive persons of their property by guile, deception, or other unfair means [3]. Moreover, fraud cases occur when forensic examiners provide various confirmed evidence or documents guaranteed for 
the court that contain deceptive or misleading information, findings and opinions, etc., consciously offered in order to shelter an unfair or unlawful gain.

A typical forensic fraud investigation consists of subsequent segments [4]. First, an analysis of the available data in order to improve a theoretical background, to determine the certain types of frauds and principals. Second, developing the existent concepts continuously, and then revising them if required, and finally confirming the modifications. Problems seem to arise when the conceptual framework of fraud detection is not appropriate. Consequently, both of these concepts must be consistent with the challenges of recent economic environments in order to be successful in uncovering any illegal business activities.

As environmental issues have become increasingly important in economic research and policy for sustainable development, firms in the private sector have introduced these risks in conducting their business activities [5]. However, while the academic literature has taken great interest in the reasons for fraud for several decades, as the 'dark side' of organizations [6], less attention has been devoted to international fraud cases in order to use different assessment methods to detect and prevent it globally.

The new institutional economics attempts to extend economics by focusing on the social and legal norms and rules that underlie economic activities [7]. The 'rules of the game' are the humanly-devised constraints that structure their interaction [8]. As of now, no clear theoretical consensus to explain the role of institutions in this perspective has yet emerged. North claimed that institutions matter, but nowadays the questions focus on what kind of characteristics and effects they should have in economies [9]. During the past decades more attention has been devoted in the economic literature to the concept of coercing, as a form of limited political institutions of governments that credibly commit the state to honor economic and political rights [10]. In this perspective, law enforcement must maintain the appearance of integrity in order to sustain institutional functionalities, i.e., to offer believable financial reports or testimony. Consequently, without maintaining the liability insurance, or keeping the faith of supervisors, the perception of institutional integrity disappears and its functionality incrementally erodes, until the institution, itself, becomes unsustainable [11].

This article examines how worldwide governance and other institutional determinants have influenced the number of reported accounting fraud cases in several countries to contribute more closely on the importance of 'good governance' as one of the indicators of development objectives in itself. The significance of our institutional perspective is to explain the complexity of accounting frauds in different societies which can be compatible for the purposes of international judgments in order to increase the effectiveness of previous forensic theories. This study contributes to the literature in two additional ways. Firstly, discussing theoretical foundations of fraud using the traditional Fraud Triangle and Fraud Diamond theories and questioning the effectiveness of these perspectives since they have provided a myopic view of multi-dimensional financial crimes. Secondly, this paper also tries to offer further explanations by incorporating multi-faceted institutional, governance, output, etc., parameters in a cross-country analysis.

The rest of this paper is organized as follows: The next section summarizes the mainstream and up-to-date conceptual evolution of forensic fraud theories. Then, in Section 3, we will briefly describe the characteristics of various governance, competitiveness, and institutional variables with common descriptive statistics. In Section 4 we will carry out various linear regression analyses with cross-country statistics in order to investigate how governance indicators can affect the number of fraud cases. The paper ends with some policy implications and conclusions in Section 5. However, our motivation is not only to suggest a feasible point of reference for researchers to detect good forensic accounting policies to reduce the fraud cases by, e.g., enhancing the control of corruption, but also to outline further research directions in this international perspective that relates to the quality of governance across countries for better development over time. 


\section{Theoretical Background}

In the 1930s, the origin of the Fraud Triangle Theory (FTT) emerged in the works of Sutherland and Locke who, for the first time, used the term white-collar crime [12]. Later, Donald Cressey was one of the first to argue that every fraud has at least three common characteristics [13]. One of the most significant elements of FTT is opportunity, where employees have a chance to commit fraud. This pressure is often another reason why someone chooses to steal when others do not. Financial pressure can arise from, e.g., personal debt, business losses, and lifestyle standards. The third point of the concept is rationalization, which is often attempted by the perpetrator to justify the crime psychologically. Regardless of the reason for taking money, the thief must try to ease the effect of distressing ethical problems related to theft. Moreover, expanding the original concept, the original FTT has been supplemented by fraud prevention and detection. FTT, later on, was extended by offering further arguments and dimensions. In the Fraud Diamond Theory (FDT), an additional element named 'capability' has been added to the three initial fraud components [14]. In other words, the potential perpetrator also needs to have the skills and ability to commit fraud.

Since then, the fraud triangle and diamond models have been the subject of several criticisms, in a way that this view of explaining financial frauds is considered a generic explanation of complex phenomenon of financial crimes and frauds. Others also criticized the triangle and diamond theories as being too limited because they provide only one physiological dimension of the initial perpetrator of the fraud [15]. In order to provide further insight for detection and prevention of frauds, researchers and practitioners have sought explanations that emphasize not only the individual factors that can contribute to corruption cases, while ignoring other social and economic factors [16]. Nevertheless, the complexity of frauds committed, and other illegal financial crimes makes it difficult to come up with one causal theory [16]. According to Morales, Gendron, and Guénin-Paracini [17], other ideas on the prevention of frauds should focus on the broader roles of, for example, society, governance programs and economic institutions. For instance, Cieslewicz [18] stated that fraud is a global problem and societal-level determinants vary across nations. Consequently, further research can be conducted to explain frauds in different societies and can assist international judgments in order to increase the effectiveness of the former FTT and FDT fraud theories. Moreover, fraud is a multifaceted phenomenon, in which related issues may not all be appropriate in one particular theoretical framework [19].

However, while the accounting literature has claimed that the presence of an increased level of fraud cases might lead to subsequent financial crises and corruption [20], over the past few decades less attention has been devoted to the concept of coercing properties. The coercive power of the governance is useful when it protects our lives and property from outside coercion, and does not tolerate infringements of liberty rights. Moreover, the concept of 'freedom from demands' is no more than that coercion and violence, fraud, and deception be prevented, except for the use of coercion by the government for the sole purpose of enforcing known rules intended to secure the best conditions under which individuals can achieve their activities in a coherent, rational pattern [21]. According to the new institutional economists, e.g., Oliver Williamson, the core 'informal' institutions (such as norms, law, and culture, etc.) are completely embodied in the stickiest 'formal' exogenous institutions of a society [22]. In this novel theoretical concept, the so-called formal institutions represent the government defined and enforced constraints, while the informal institutions capture the private ones. In this context the formal institutions are only beneficial in the presence of particular informal institutions of governance and the interactions of actors [23]. Additionally, other theorists emphasize the importance of the legal environment in which markets operate [24]. Hence, one of the chief purposes of this research study is to investigate the valid relations among international forensic fraud cases and worldwide governance, etc., in the context of institutional economics. Consequently, our research questions are the following: (1) What are the contributions of worldwide governance to the level of fraud in a cross-country perspective? (2) How is global competitiveness related to the number of accounting fraud cases? (3) Do countries with effective legal systems reveal more fraud cases than 
countries with ineffective ones? Based on these questions and findings of the literature reviewed above, the current study forms the following hypothesis:

H1. The worldwide governance might influence the level of fraud cases.

Finally, our objective is to draw some conclusions and policy suggestions in order to support a better understanding of governance for business organizations, highlighting the importance of the institutional environment.

\section{Data and Methodologies}

Our estimations are commonly based on a linear regression model (OLS) (see Equation (1)) with heteroscedasticity consistent standard errors, in which number of fraud cases in logs at country [i] can be written as described by Long and Ervin [25]:

$$
\begin{aligned}
& \ln \left(\text { fraud }_{i}=\beta_{\mathrm{o}}+\beta_{1} \mathrm{COC}_{\mathrm{i}}+\beta_{2} \mathrm{GOE}_{\mathrm{i}}+\beta_{3} \mathrm{POS}_{\mathrm{i}}+\beta_{4} \mathrm{REQ}_{\mathrm{i}}+\beta_{5} \mathrm{RLV}_{\mathrm{i}}+\right. \\
& \beta_{6} \mathrm{VOA}_{\mathrm{i}}+\beta_{7} \ln (\mathrm{GDP})_{\mathrm{i}}+\beta_{8} \ln (\mathrm{GCI})_{\mathrm{i}}+\beta_{9} \text { DOrigin }_{\mathrm{i}}+\varepsilon_{\mathrm{i}}
\end{aligned}
$$

This model is tested in the case of 2014 and 2016, where the notation uses the standard abbreviations:

$\ln$ (fraud) represents the number (level) of fraud cases. Organizations face numerous economic risks to their success in different ways and to varying degrees. The risk of fraud is just one of the many faced by all business and government entities. The Report to the Nation on Occupational Fraud and Abuse (ACFE) has been published biannually since 1996 by the Association of Certified Fraud Examiners and the numbers of fraud cases have been collected from the last available reports [3]. The ACFE is the world's largest anti-fraud organization and premier provider of anti-fraud training education and certification. In addition to looking at the overall percentage of accounting fraud cases, we will also compare them regionally. Figure 1 shows the proportion of cases in each region in 2016, using a total of 102 countries. The highest proportion of cases was in the Sub-Saharan region $(28.13 \%)$, while the Middle East and North Africa had the lowest (7.8\%) proportion.

$\mathrm{COC}$ is the variable of Control of Corruption, which captures perceptions of the extent to which public power is exercised for private gain, including both petty and grand forms of corruption, as well as 'capture' of the state by elites and private interests [26].

GOE stands for Government Effectiveness and captures perceptions of the quality of public services, the quality of the civil service and the degree of its independence from political pressures, the quality of policy formulation and implementation, and the credibility of the government's commitment to such policies [26].

POS is Political Stability and Absence of Violence/Terrorism, and measures perceptions of the likelihood of political instability and/or politically-motivated violence, including terrorism [26].

REQ stands for Regulatory Quality, which captures perceptions of the ability of the government to formulate and implement sound policies and regulations that permit and promote private sector development [26].

RLW denotes Rule of Law and captures perceptions of the extent to which agents have confidence in and abide by the rules of society, and in particular the quality of contract enforcement, property rights, the police, and the courts, as well as the likelihood of crime and violence [26].

VOA stands for Voice and Accountability and captures perceptions of the extent to which a country's citizens are able to participate in selecting their government, as well as freedom of expression, freedom of association, and a free media [26].

The Worldwide Governance Indicators (WGI) project constructs aggregate and standardized indicators of the listed variables which are comprehensive dimensions of governance. These indicators are: Control of Corruption (COC), Government Effectiveness (GOE), Political Stability and Absence of Violence/Terrorism (POS), Regulatory Quality (REQ), the Rule of Law (RLW) and, finally, Voice and Accountability (VOA). These aggregate indicators are based on more than 30 fundamental data sources 
reporting the perceptions of governance of a huge number of respondents and expert assessments worldwide [27].

GDP is one of the control variables of our model that represents the log of real GDP at constant 2011 national prices (in million US\$) from the Penn World Table [28], with thanks to Feenstra, Inklaar, and Timmer [29].

GCI denotes the World Bank's Global Competitiveness Index (GCI) in a logarithm, based on approximately a dozen pillars [30]. For example, institutions, macroeconomic environment, health, higher education and training, goods and labor market efficiency, financial market development, market size, business sophistication, and innovation, etc. These sub-indices are given different weights in the calculation of the overall index, depending on each countries' economic stage of development, as substituted by its GDP percentage and share of exports represented by mineral raw materials.

$\mathrm{D}$ (Origin) represents dummy variables that identify the legal origin of the Company Law or Commercial Code of each country. The four origins of law are English, French, German, and Nordic as a reference, respectively. For instance, $1=$ English and 0 otherwise, etc. $\varepsilon$ is the error term.

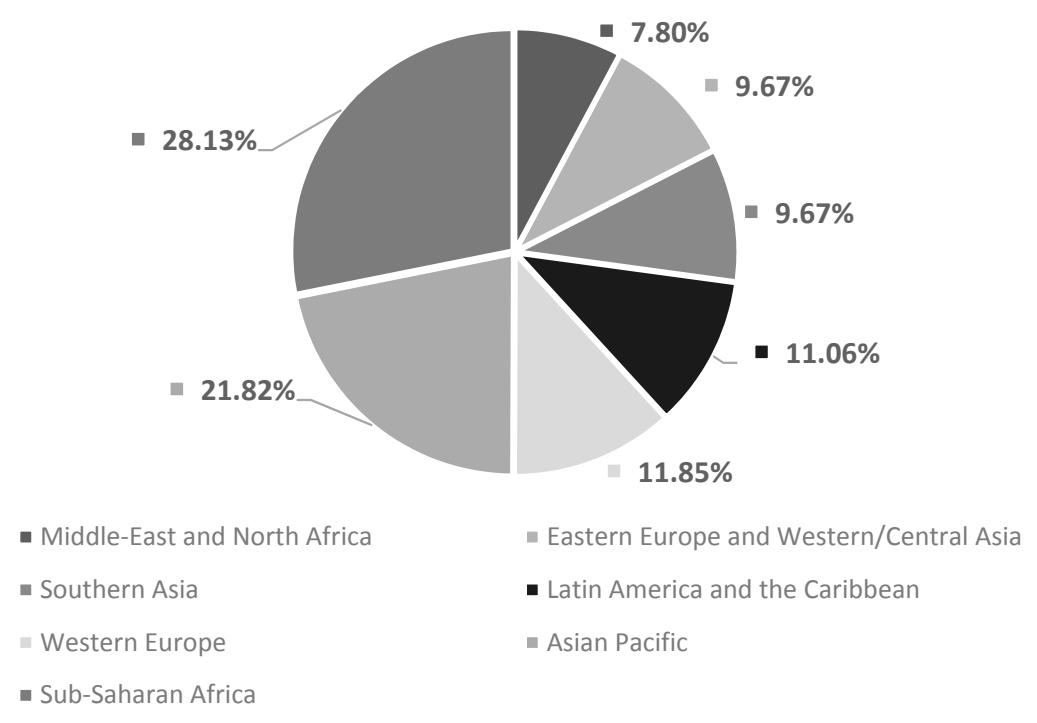

Figure 1. The proportion of fraud cases * by region in 2016. Source: based on [3]. Notes: *: the total number of forensic cases was 1024. Examined countries (102) in alphabetic order of appearance: Albania, Algeria, Argentina, Armenia, Australia, Austria, Bahrain, Bangladesh, Belgium, Bolivia, Botswana, Brazil, Bulgaria, Cameroon, Canada, Chile, China, Colombia, Côte d'Ivoire, Cyprus, Czech Republic, D. R. of the Congo, Denmark, Ecuador, Egypt, Finland, France, Gabon, Gambia, Germany, Ghana, Greece, Guatemala, Honduras, Hungary, India, Indonesia, Ireland, Israel, Italy, Jamaica, Japan, Jordan, Kazakhstan, Kenya, Korea (South), Kosovo, Kuwait, Laos, Lebanon, Lesotho. Liberia, Malawi, Malaysia, Mali, Mauritania, Mauritius, Mexico, Montenegro, Namibia, Nepal, Netherlands, New Zealand, Nicaragua, Nigeria, Oman, Pakistan, Panama, Peru, Philippines, Poland, Portugal, Qatar, Romania, Russia, Saudi Arabia, Senegal, Serbia, Sierra Leone, Singapore, Slovakia, Slovenia, Somalia, South Africa, South Sudan, Spain, Sudan, Switzerland, Taiwan, Tanzania, Thailand, The United States of America, Trinidad and Tobago, Turkey, Uganda, Ukraine, United Arab Emirates, United Kingdom, Vietnam. Zambia, and Zimbabwe.

\section{Results and Discussion}

Table 1 shows certain descriptive statistics (mean, median, standard deviation, and skewness, etc.) and the normality tests of the variables used in the regressions are reported. In some applications, especially with cross-sectional data, all observations are assumed to be independent and have identical distribution [31]. In the case of fraud, output and competitiveness (GCI) the log transformations are used to transform skewed data to increase the validity and explanatory power of the associated 
statistical analyses [32]. The authors [27] normalize the World Governance Indicators, so additional transformation is not needed, respectively. Moreover, the reported Shapiro-Wilk tests for normality in both variables and the Doornik-Hansen test for multivariate normality strengthened the validity of normal distributions in both cases.

Table 1. The descriptive statistics of Equation (1) variables.

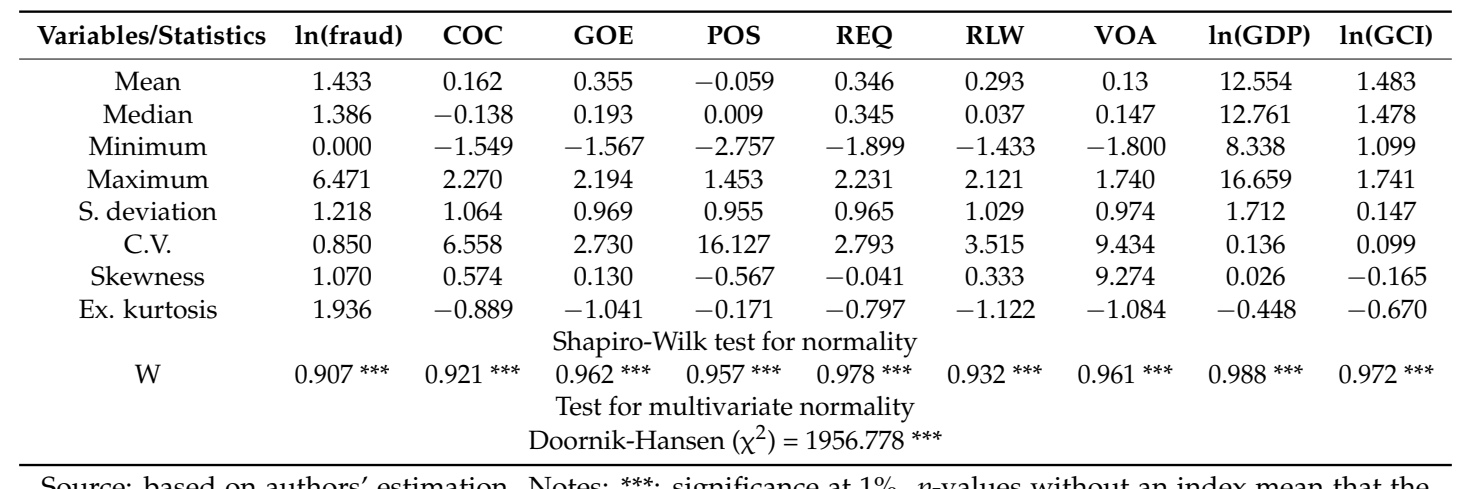

Source: based on authors' estimation. Notes: ${ }^{* * *}$ : significance at $1 \% . p$-values without an index mean that the coefficient is not significant, even at the $10 \%$ level.

The effect of worldwide governance indicators contribute to the growing empirical research in governance, which has provided efficient tools for policy reform and monitoring. Using Equation (1) our regression models the influence of these variables on the number of accounting frauds tested in a cross-country specific perspective. Tables 2 and 3 represent the corresponding results of our estimations in each model.

Table 2. Results of the heteroscedasticity corrected OLS regressions of Equation (1) in the examined countries in 2014.

\begin{tabular}{|c|c|c|c|c|c|c|c|c|}
\hline $\begin{array}{c}\text { Independent } \\
\text { Variables }\end{array}$ & Model 1 & Model 2 & Model 3 & Model 4 & Model 5 & Model 6 & Model 7 & Model 8 \\
\hline \multirow[t]{2}{*}{ Constant } & 1.129 & 1.210 & -4.542 & -3.375 & -0.449 & -0.536 & -5.798 & -3.127 \\
\hline & $8.415^{* * *}$ & $9.66^{* * *}$ & $\underset{* * *}{-5.608}$ & -4.456 & $-1.850^{*}$ & $-2.352 *$ & $\begin{array}{c}-8.699 \\
* * *\end{array}$ & $-2.553^{* *}$ \\
\hline \multirow[t]{2}{*}{ COC } & -0.549 & & -0.756 & & -0.663 & -0.497 & & \\
\hline & 0.456 & & $-1.968^{*}$ & & $-1,654$ & $-1.9920 *$ & & \\
\hline \multirow[t]{2}{*}{ GOE } & 0.995 & 0.631 & -0.298 & & 1.252 & 1.079 & & \\
\hline & $2.201 * *$ & $3.027^{* * *}$ & -0.298 & & $3.230^{* * *}$ & $3.903^{* * *}$ & & \\
\hline \multirow[t]{2}{*}{ POS } & -0.550 & -0.654 & 0.080 & & -0.498 & 0.344 & & \\
\hline & $-2.593^{* *}$ & $-\underset{* * *}{2.933}$ & 0.142 & & $\begin{array}{c}-2.962 \\
* * *\end{array}$ & $-2.544^{* *}$ & & \\
\hline \multirow[t]{2}{*}{ REQ } & -0.523 & & 0.149 & & -0.305 & & & \\
\hline & -1.434 & & 0.436 & & -1.127 & & & \\
\hline \multirow[t]{2}{*}{ RLW } & 0.660 & & 0.687 & & 0.315 & & & \\
\hline & 1.130 & & 1.438 & & 0.664 & & & \\
\hline \multirow[t]{2}{*}{ VOA } & 0.021 & 0.019 & 0.017 & 0.017 & 0.016 & 0.046 & & \\
\hline & $4.654^{* * *}$ & $5.668^{* * *}$ & $4.275^{* * *}$ & $6.680^{* * *}$ & $3.815^{* * *}$ & $3.593^{* * *}$ & & \\
\hline \multirow[t]{2}{*}{$\ln (\mathrm{GDP})$} & & & 0.464 & 0.376 & & & 0.464 & \\
\hline & & & $6.735^{* * *}$ & $6.063 * * *$ & & & $8.879^{* * *}$ & \\
\hline \multirow[t]{2}{*}{$\ln (\mathrm{GCI})$} & & & & & & & & 1.855 \\
\hline & & & & & & & & $2.553^{* *}$ \\
\hline \multirow[t]{2}{*}{ English } & & & & & 1.910 & 1.954 & 2.026 & 2.439 \\
\hline & & & & & $6.007^{* * *}$ & $5.406^{* * *}$ & $9.354^{* * *}$ & $6.947^{* * *}$ \\
\hline \multirow[t]{2}{*}{ French } & & & & & 1.215 & 2.02553 & 1.242 & 1.617 \\
\hline & & & & & $4.335^{* * *}$ & $5.289 * * *$ & $6.934^{* * *}$ & $6.372^{* * *}$ \\
\hline \multirow[t]{2}{*}{ German } & & & & & 1.378 & 1.425 & 0.940 & 1.626 \\
\hline & & & & & $3.362 * * *$ & $3.544^{* * *}$ & $2.253 * *$ & $4.652 * * *$ \\
\hline Observation & 89 & 89 & 89 & 89 & 67 & 67 & 66 & 63 \\
\hline Adjusted $\mathrm{R}^{2}$ & 0.826 & 0.793 & 0.891 & 0.861 & 0.983 & 0.981 & 0.680 & 0.665 \\
\hline F-test & $70.67^{* * *}$ & $113.41^{* * *}$ & $102.66^{* * *}$ & $287.28^{* * *}$ & $451.61^{* * *}$ & $486.36^{* * *}$ & $35.56^{* * *}$ & $31.88^{* * *}$ \\
\hline
\end{tabular}

Source: calculations based on $[3,26,28,30]$. Notes: Heteroscedasticity robust t-statistics are in parentheses. Letters in the upper index refer to significance: ${ }^{* * *}$ : significance at $1 \%,{ }^{* *}: 5 \%,{ }^{*}: 10 \%$. $p$-values without an index mean that the coefficient is not significant, even at the $10 \%$ level. 
Table 3. Results of the heteroscedasticity corrected OLS regressions of Equation (1) in the examined countries in 2016.

\begin{tabular}{|c|c|c|c|c|c|c|}
\hline Independent Variables & Model 9 & Model 10 & Model 11 & Model 12 & Model 13 & Model 14 \\
\hline \multirow[t]{2}{*}{ Constant } & 1.221 & 2.221 & -0.402 & & -2.661 & -5.292 \\
\hline & $10.27^{* * *}$ & $10.27^{* * *}$ & -0.942 & & $-2.335^{* *}$ & $-4.209^{* * *}$ \\
\hline \multirow[t]{2}{*}{$\mathrm{COC}$} & -0.097 & & -0.917 & -0.925 & & \\
\hline & -0.2800 & & $-2.675^{* * *}$ & $-3.253^{* * *}$ & & \\
\hline \multirow[t]{2}{*}{ GOE } & 0.346 & 1.035 & 1.533 & 1.551 & & \\
\hline & 0.804 & $5.654^{* * *}$ & $3.161 * * *$ & $4.589^{* * *}$ & & \\
\hline \multirow[t]{2}{*}{ POS } & -0.631 & -0.641 & -0.955 & -0.842 & & \\
\hline & $-3.986^{* * *}$ & $-4.922 * * *$ & $-5.348^{* * *}$ & $-4.666^{* * *}$ & & \\
\hline \multirow[t]{2}{*}{ REQ } & 0.190 & & -0.212 & & & \\
\hline & 0.363 & & -0.558 & & & \\
\hline \multirow[t]{2}{*}{ RLW } & 0.190 & & -0.212 & & & \\
\hline & 0.363 & & 0.903 & & & \\
\hline \multirow[t]{2}{*}{ VOA } & -0.004 & & 0.681 & 0.612 & & \\
\hline & -0.026 & & $3.279 * * *$ & $3.363^{* * *}$ & & \\
\hline \multirow[t]{2}{*}{$\ln (\mathrm{GCI})$} & & & & & 3.029 & 3.674 \\
\hline & & & & & $3.863^{* * *}$ & $4.986^{* * *}$ \\
\hline \multirow[t]{2}{*}{ English } & & & 1.941 & 1.132 & & 2.239 \\
\hline & & & $4.132 * * *$ & $3.462 * * *$ & & $5.450 * * *$ \\
\hline \multirow[t]{2}{*}{ French } & & & 1.328 & 0.542 & & 1.562 \\
\hline & & & $2.816^{* * *}$ & $1.187^{* *}$ & & $4.482 * * *$ \\
\hline \multirow{2}{*}{ German } & & & 0.742 & & & 0.963 \\
\hline & & & 0.127 & & & $3.686^{* * *}$ \\
\hline Observation & 102 & 102 & 74 & 74 & 95 & 70 \\
\hline Adjusted $R^{2}$ & 0.195 & 0.231 & 0.563 & 0.421 & 0.138 & 0.372 \\
\hline F-test & $5.079 * * *$ & $16.19^{* * *}$ & $9.171^{* * *}$ & $9.848^{* * *}$ & $14.92 * * *$ & $9.66^{* * *}$ \\
\hline
\end{tabular}

Source: calculations based on $[3,26,30]$. Notes: Heteroscedasticity robust t-statistics are in parentheses. Letters in the upper index refer to significance: ${ }^{* * *}$ : significance at $1 \%, * *: 5 \%, *: 10 \%$. $p$-values without an index mean that the coefficient is not significant, even at the 10\% level. GDP has not been available in 2016 at the PWT [28], which resulted in fewer model specifications.

Table 2 summarizes the results of the heteroscedasticity-corrected OLS regressions in the examined countries in 2014. In order to check the robustness of our specifications, our models will be simultaneously tested by the samples of fraud cases reported by ACFE in 2016, in Table 3. In the bottom section of these tables, the significant F-tests statistics suggest that our linear regression specification should be preferred in all models. Appendix A includes the correlation matrix of the independent variables. In the case of Model 2, 4, 6, 8, 10, and 12 only the effects of the significant variables are listed, and the others are omitted to increase the explanatory power of the previously tested models $(1,3,5,7,9$, and 11$)$.

In Model 6, 10, and 11 the impact of the control of corruption (COC) variable is robust and also has significant negative t-statistics. In other words, as theoretically assumed, more controlled corruption might decrease the number of fraud cases. Political Stability and Absence of Violence (POS) is also negatively correlated with the dependent fraud variable in our models, the only exception is Model 3. From this point of view, more political stability with less violence negatively affects forensic crime cases (GDP has not been available for 2016 resulting in less model-specifications in Table 2). Meanwhile, the Government Effectiveness (GOE) and Voice and Accountability (VOA) ratios are obviously positively related to fraud cases in our models. If there is one unit increase in the level of the quality and effectiveness of governance services, then more stated and accountable forensic fraud cases seemed to appear.

Thus, there were no valid relationships between the Rule of Law (RLW) and Regulatory Quality (REQ) variables and the number of reported fraud cases in our estimations. Lack of significance, in this case, could only mean that the changing nature or level of these institutions does not indicate forensic violation in the examined countries and years at a given level of other determinants.

The impacts of the log of GDP and Global Competitiveness (GCI) index are robust in Models 3 and 4 and Models 8, 13, and 14, and as we earlier expected, have correspondingly significant positive t-statistics. Podobnik et al. also found that the dynamics of GDP, GCI, and corruption might 
share the same origin [33]. They defined the GCI of economies as the set of institutions, policies, and factors that can determine the level of productivity. This index of competitiveness quantifies how productive a country is at using more resources that become available. Obviously, the supplementary level of corruption strongly reduces a country's prospects for an improvement in its wealth [34]. Thus, the correlation between the inverse corruption and competitiveness indices is very strong, which means that a high level of corruption has a significant negative impact on national competitiveness [35]. Assuming that there is a valid relationship between the competitiveness and economic growth of a given country, we can also claim that an increased level of these two factors positively influences the reported fraud cases.

Our results also found that legal origin is one of the determinants which also affects the number of fraud cases. Both of the legal origin dummies were significant in our models. Moreover, when comparing two countries, an English country and a country with a different origin, the Anglo-Saxon countries have more stated forensic fraud cases than the others. These findings seemed to agree with La Porta et al. [36], as they claimed that Britain has perhaps the best commercial courts in the world, with the most professional and least corrupt judges, and centuries of precedents and experience in dealing with fraud. Indeed, those countries that have better laws, a more effective judicial system, decent financial reporting standards, and a higher concentration of accountants are found to be less corrupt [37].

\section{Conclusions}

Although the Worldwide Governance Indicators have come to be one of the most broadly used indicators of governance by policy-makers and academics in recent years, several critiques have been made regarding substantial problems in their methodologies. These criticisms have emphasized that many of the indicators are not published, nor reproducible [38]. Others have highlighted the hidden measurement biases, and also the absence of an underlying normative concept of 'good' governance' for decision-makers [39]. Moreover, additional limitations of this approach are that it lacks comparability over time and space, and also offers minor guidance for concrete arrangements to improve the quality of governance [40].

The impact of each pillar of governance or competitiveness varies across countries and these indices are calculated using different weights, depending on the function of their stages of economic development. Essentially, based on our results, we can merely claim that the increased level of control over corruption and political stability might reduce the number of fraud cases, and more effective and independent governance services with a higher level of freedom of expression seems to increase forensic crime. The existing number of these cases also appears to be a suitable proxy for better competitiveness.

The main importance and contribution of these results are demonstrating that the earlier fraud triangle and diamond theories are misdirected and lead to inaccurate, misleading conclusions. Thus, additional dimensions are suggested so that a more comprehensive model may be developed that can consider, explicitly, financial crime in order to guide future theoretical and empirical studies. Essentially, the complexity of accounting fraud in different societies can be compatible for the purposes of international judgments in order to increase the effectiveness of forensic theories in our institutional perspective and engage the 'best' governance policies in practice. According to our results the Global Competitiveness Index (GCI) of economies as the set of institutions, policies, and factors positively influence the number of fraud cases. Moreover, we also found that legal origin is one of the institutional determinants which also affects the number of financial crimes. These evidences also suggest it is worth monitoring the quality of governance across and within individual countries for better development over time. From another point of view, the existing financial challenges regarding, i.e., debt enforcement, risk management [41], organizational culture [42] and trust [43], etc. represent a respectable opportunity for further research in the case of accounting fraud analysis. 
An understanding of the principle elements of fraud is the foundation for any antifraud activity, whether it is developing a fraud policy, investigating, or designing antifraud controls. Moreover, fraud cases resemble snowflakes in that none of them are alike, and each one needs to be treated as a separate case [44]. Hence, the development of an effective response plan includes an effective anti-fraud policy. So far, anti-corruption has remained a priority in the European Semester process of economic governance. Several recommendations have been made to improve transparency and/or step-up anti-corruption efforts in public administration and judiciary procurement, etc. [45]. Meanwhile, the European Anti-fraud Office (OLAF) also negotiates provisions in EU international agreements, such as association and partnership settlements with the objective of strengthening inspective cooperation beyond their borders. The objective of the Commission's Anti-Fraud Strategy (CAFS) is to improve prevention, and promote the investigation of fraud, corruption, and any other illegal activities affecting financial interests [46].

Nevertheless, if accounting regulation is not a critical focus of corporate governance within an organization, even more fraud cases can potentially occur. Consequently, the corporations should be accountable for all violations of those standards, such as the Sarbanes-Oxley Act (SOX) to pay close attention to avoid any conflicts of shareholder interests. However, while these legislation systems are regulating corporations to practice accountability, and judging by the increase in repeat violations, corporations are failing to act responsibly [47].

The main limitation of our estimations also needs to be emphasized and that is that these empirical findings were only able to demonstrate one empirical aspect of forensic frauds. Meanwhile, other determinants which may affect the reported cases have not been included due to restricted access to data, so the validity of our conclusions is limited by the bias caused by the exclusion of these variables and method. Despite the above noted limitations and concerns our research looking at how reliable some of the governance etc. indicators are, and concluded that the governance indicators do in fact seem to be measure the levels of fraud, corruption, and government effectiveness [48].

However, we believe that a better understanding of fraud detection is a potentially important element in forensic analytics in the success of governance policies to resolve the negative outcomes of forthcoming financial crises [49]. Hence, in this international approach further research could be fruitful and significant in the future.

Acknowledgments: Supported by the ÚNKP-17-4-III New National Excellence Program of the Ministry of Human Capacities.

Author Contributions: D.M., R.S., and J.P. conceived, designed and performed the experiments; D.M. J.O., and R.S. analyzed the data and wrote the paper; and J.O. contributed materials and analysis tools.

Conflicts of Interest: The authors declare no conflict of interest.

\section{Appendix}

Table A1. The correlation matrix of the dependent variables of Equation (1).

\begin{tabular}{ccccccccc}
\hline $\begin{array}{c}\text { Independent } \\
\text { Variables }\end{array}$ & COC & GOE & POS & REQ & RLW & VOA & $\ln (G D P)$ & $\ln (G C I)$ \\
\hline COF & 1.000 & & & & & & & \\
GOE & -0.702 & 1.000 & & & & & \\
POS & -0.497 & 0.106 & 1.000 & & & & \\
REQ & 0.109 & -0.441 & 0.091 & 1.000 & & & \\
RLW & -0.092 & -0.052 & -0.248 & -0.547 & 1.000 & & \\
VOA & -0.812 & 0.561 & 0.686 & 0.017 & -0.304 & 1.000 & & \\
$\ln (\mathrm{GDP})$ & 0.282 & -0.098 & -0.339 & -0.259 & 0.280 & -0.225 & 1.000 & \\
$\ln (\mathrm{GCI})$ & -0.805 & 0.432 & 0.762 & 0.051 & -0.166 & 0.764 & -0.511 & 1.000 \\
\hline \multicolumn{7}{c}{ Source: based on authors' estimation. }
\end{tabular}




\section{References}

1. Lerner, K.L.; Lerner, B.W. World of Forensic Science; Thomson/Gale: Farmington Hills, MI, USA, 2006, ISBN 1414402953.

2. Garner, B.A.; Black, H.C. Black's Law Dictionary; Thomson/West: Egon, MN, USA, 2004, ISBN 978-0-31-415199-5.

3. Association of Certified Fraud Examiners (ACFE). Report to the Nations Detection: On Occupational Fraud and Abuse; ACFE: Austin, TX, USA, 2016.

4. Dorminey, J.W.; Fleming, A.S.; Kranacher, M.-J.; Riley, R.A. Beyond the Fraud Triangle. CPA J. 2010, 80, 41-54.

5. Hoti, S.; McAleer, M.; Pauwels, L.L. Modelling Environmental Risk. Environ. Model. Software 2005, 20, 1289-1298. [CrossRef]

6. Vaughan, D. The Dark Side of Organizations: Mistake, Misconduct, and Disaster. Annu. Rev. Sociol. 1999, 25, 271-305. [CrossRef]

7. Rutherford, M. Institutional Economics: Then and Now. J. Econ. Perspect. 2001, 15, 173-194. [CrossRef]

8. North, D.C. Economic Performance through Time. Am. Econ. Rev. 1994, 84, 359-368. [CrossRef]

9. North, D.C. Institutions, Ideology, and Economic Performance. Cato J. 1991, 11, 477-496.

10. Weingast, B.R. The Economic Role of Political Institutions: Market-Preserving Federalism and Economic Development. J. Law Econ. Organ. 1995, 11, 1-31. [CrossRef]

11. Turvey, B.E. Forensic Fraud: Evaluating Law Enforcement and Forensic Science Cultures in the Context of Examiner Misconduct; Academic Press: Cambridge, MA, USA, 2013, ISBN 0124080731.

12. Sutherland, E.H.; Locke, J. Twenty Thousand Homeless Men: A Study of Unemployed Men in the Chicago Shelters; Arno Press: New York, NY, USA, 1936.

13. Clinard, M.B.; Cressey, D.R. Other People's Money: A Study in the Social Psychology of Embezzlement. Am. Sociol. Rev. 1954, 19, 362. [CrossRef]

14. Wolfe, D.T.; Hermanson, D.R. The Fraud Diamond: Considering the Four Elements of Fraud. CPA J. 2004, 74, $38-42$.

15. Albrecht, W.S.; Albrecht, C.; Albrecht, C.C. Current Trends in Fraud and its Detection. Inf. Secur. J. Glob. Perspect. 2008, 17, 2-12. [CrossRef]

16. Free, C. Looking through the fraud triangle: A review and call for new directions. Meditari Account. Res. 2015, 23, 175-196. [CrossRef]

17. Morales, J.; Gendron, Y.; Guénin-Paracini, H. The construction of the risky individual and vigilant organization: A genealogy of the fraud triangle. Account. Organ. Soc. 2014, 39, 170-194. [CrossRef]

18. Cieslewicz, J.K. The Fraud Model in International Contexts: A Call to Include Societal-Level Influences in the Model. J. Forencic Investig. Account. 2012, 4, 214-254.

19. Lokanan, M.E. Challenges to the fraud triangle: Questions on its usefulness. Account. Forum 2015, 39, 201-224. [CrossRef]

20. Krambia-Kapardis, M. Financial Crisis, Fraud, and Corruption. In Corporate Fraud and Corruption; Palgrave Macmillan US: New York, NY, USA, 2016; pp. 5-38.

21. Hayek, F. The Constitution of Liberty: The Definitve Edition; University of Chicago Press: Chicago, IL, USA, 1960, ISBN 978-0-22-632084-7.

22. Williamson, O.E. The New Institutional Economics: Taking Stock, Looking Ahead. J. Econ. Lit. 2000, 38, 595-613. [CrossRef]

23. Williamson, C.R. Informal institutions rule: Institutional arrangements and economic performance. Public Choice 2009, 139, 371-387. [CrossRef]

24. Boettke, P.J.; Coyne, C.J.; Leeson, P.T. Institutional Stickiness and the New Development Economics. Am. J. Econ. Sociol. 2008, 67, 331-358. [CrossRef]

25. Long, J.S.; Ervin, L.H. Using Heteroscedasticity Consistent Standard Errors in the Linear Regression Model. Am. Stat. 2000, 54, 217-224. [CrossRef]

26. The World Bank Worldwide Governance Indicators Data. Available online: https://data.worldbank.org/dat a-catalog/worldwide-governance-indicators (accessed on 3 January 2018).

27. Kaufmann, D.; Kraay, A.; Mastruzzi, M. The Worldwide Governance Indicators: Methodology and Analytical Issues; Policy Research Working Paper Series 5430; The World Bank: Washington, DC, USA, 2010.

28. Penn World Table (PWT) 9.0. Available online: https://www.rug.nl/ggdc/productivity/pwt/ (accessed on 3 January 2018). 
29. Feenstra, R.C.; Inklaar, R.; Timmer, M.P. The Next Generation of the Penn World Table. Am. Econ. Rev. 2015, 105, 3150-3182. [CrossRef]

30. The World Bank Global Competitiveness Index. Available online: https://tcdata360.worldbank.org/indica tors $/$ gci? country=HUN\&indicator=631\&viz=line_chart\&years=2007,2016 (accessed on 4 January 2018).

31. Strickland, J. Predictive Analytics Using R; LULU COM: Morrisville, NC, USA, 2014, ISBN 978-1-31-284101-7.

32. Feng, C.; Wang, H.; Lu, N.; Chen, T.; He, H.; Lu, Y.; Tu, X.M. Log-transformation and its implications for data analysis. Shanghai Arch. Psychiatry 2014, 26, 105-109. [CrossRef] [PubMed]

33. Podobnik, B.; Horvatić, D.; Kenett, D.Y.; Stanley, H.E. The competitiveness versus the wealth of a country. Sci. Rep. 2012, 2, 678. [CrossRef] [PubMed]

34. Mo, P.H. Corruption and Economic Growth. J. Comp. Econ. 2001, 29, 66-79. [CrossRef]

35. Ulman, S.-R. Corruption and National Competitiveness in Different Stages of Country Development. Procedia Econ. Financ. 2013, 6, 150-160. [CrossRef]

36. La Porta, R.; Lopez-de-Silanes, F.; Shleifer, A.; Vishny, R.W. Law and Finance. J. Political Econ. 1998, 106, 1113-1155. [CrossRef]

37. Kimbro, M.B. A Cross-Country Empirical Investigation of Corruption and its Relationship to Economic, Cultural, and Monitoring Institutions: An Examination of the Role of Accounting and Financial Statements Quality. J. Account. Audit. Financ. 2002, 17, 325-350. [CrossRef]

38. Arndt, C.; Oman, C. The Politics of Governance Ratings; MGSoG: Maastricht, The Netherlands, 2008.

39. Thomas, M.A. What Do the Worldwide Governance Indicators Measure? Eur. J. Dev. Res. 2010, $22,31-54$. [CrossRef]

40. Langbein, L.; Knack, S. The Worldwide Governance Indicators: Six, One, or None? J. Dev. Stud. 2010, 46, 350-370. [CrossRef]

41. Tálas, D.; Rózsa, A. Financial competitiveness analysis in the Hungarian dairy industry. Compet. Rev. 2015, 25, 426-447. [CrossRef]

42. Brodbeck, F.C.; Frese, M.; Akerblom, S.; Audia, G.; Bakacsi, G.; Bendova, H.; Bodega, D.; Bodur, M.; Booth, S.; Brenk, K.; et al. Cultural variation of leadership prototypes across 22 European countries. J. Occup. Organ. Psychol. 2000, 73, 1-29. [CrossRef]

43. Oláh, J.; Bai, A.; Karmazin, G.; Balogh, P.; Popp, J. The Role Played by Trust and Its Effect on the Competiveness of Logistics Service Providers in Hungary. Sustainability 2017, 9, 2303. [CrossRef]

44. Singleton, T.; Singleton, A.J. Fraud Auditing and Forensic Accounting; Wiley: Hoboken, NJ, USA, 2010, ISBN 978-0-47-056413-4.

45. European Comission. Protection of the European Union's Financial Interests_Fight against Fraud-2015 Annual Report; European Comission: Brussels, Belgium, 2015.

46. European Commission. Communication from the Commission to the European Parliament, the Council, the European Economic and Social Committee, the Committee of the Regions and the European Investment Bank-On the Comission Anti-Fraud Strategy; European Comission: Brussels, Belgium, 2015.

47. Williams, T. Role of Management, Corporate Governance, and Sarbanes-Oxley in Fraud: A Focus on the Precious Metals Industry; Springer: Singapore, 2018; pp. 391-409.

48. Hamilton, A.; Hammer, C. Can We Measure the Power of the Grabbing Hand? A Comparative Analysis of Different Indicators of Corruption; Policy Research Working Paper; The World Bank: Washington, DC, USA, 2017.

49. Máté, D.; Sadaf, R.; Tarnóczi, T.; Fenyves, V. Fraud Detection by Testing the Conformity to Benford's Law in the Case of Wholesale Enterprises. Pol. J. Manag. Stud. 2017, 16, 115-126. [CrossRef]

(C) 2018 by the authors. Licensee MDPI, Basel, Switzerland. This article is an open access article distributed under the terms and conditions of the Creative Commons Attribution (CC BY) license (http://creativecommons.org/licenses/by/4.0/). 